\title{
Hukuman Mati Bagi Koruptor Pada Saat Keadaan Tertentu (Pandemi COVID-19) Perspektif Hukum Nasional dan Hukum Islam
}

\author{
Dahyul Daipon \\ Fakultas Syariah IAIN Bukittinggi \\ Kubang Putiah, Kec. Aur Birugo Tigo Baleh, Kabupaten Agam, Sumatera Barat \\ Email:dahyuldaipon55@gmail.com
}

\begin{tabular}{llll} 
Submit & $: 24$ Februari 2021 & Diterima & $:$ 26 Februari 2021 \\
Revisi & $: 27$ Maret 2021 & Terbit & $:$ 11 Juni 2021 \\
\hline
\end{tabular}

\begin{abstract}
The current condition of the Covid-19 pandemic is a time where almost everyone feels social and economic difficulties. Communities whose regions apply restrictions/quarantines are highly dependent on assistance from the government. This paper is a study and analysis of one question how the death penalty can be applied to perpetrators of corruption during the Covid-19 outbreak or pandemic. In the criminal law that applies in Indonesia, the death penalty for perpetrators of criminal acts of corruption is contained in Article 2 paragraph 2 of Law no. 31 of 1999 concerning the Eradication of Corruption Crimes. Meanwhile, in Islamic law, corruption is categorized as jarimah ta'zir. The results of this study conclude that during a pandemic, the death penalty can be applied to corruptors in accordance with the provisions of Article 2 of the Anti-Corruption Law and the provisions of Islamic criminal law as jarimah ta'zir. There are fundamental differences in the application of the death penalty for corruptors according to positive law and Islamic criminal law, especially with regard to the conditions required for the imposition of the death penalty. Even though this seems cruel according to human rights supporters, this needs to be a concern for all law enforcers so that they can carry out strict law enforcement against perpetrators of corruption crimes during the pandemic.
\end{abstract}

Keywords: Islam law, punishment, corruption, pandemic, Covid-19

Abstrak: Kondisi pandemi Covid-19 saat ini merupakan masa di mana hampir semua orang merasa kesulitan secara sosial dan ekonomi. Masyarakat yang daerahnya menerapkan pembatasan/karantina sangat bergantung pada bantuan dari pemerintah. Tulisan ini merupakan kajian dan analisis atas satu pertanyaan bagaimana hukuman mati dapat diterapkan pada pelaku tindak pidana korupsi pada saat terjadi wabah ataupun pandemi Covid-19. Dalam hukum pidana nasional Indonesia, hukuman mati bagi pelaku tindak pidana korupsi terdapat di dalam Pasal 2 ayat 2 UU No. 31 tahun 1999 tentang Pemberantasan Tindak Pidana Korupsi. Sedangkan dalam hukum Islam, tindak pidana korupsi masuk kategori jarimah ta'zir. Hasil kajian ini menyimpulkan bahwa saat terjadi pandemi, pidana mati dapat diterapkan kepada koruptor sesuai dengan ketentuan Pasal 2 UU Tipikor maupun ketentuan hukum pidana Islam sebagai jarimah ta'zir. Terdapat perbedaan yang mendasar dalam hal penerapan hukuman mati bagi koruptor menurut hukum positif dan hukum pidana Islam, terutama berkaitan dengan syarat-syarat yang dibutuhkan dalam penjatuhan hukuman mati tersebut. Walaupun hal itu terlihat kejam menurut pendukung HAM, namun hal ini perlu menjadi perhatian bagi semua penegak hukum agar dapat menjalankan penerapan hukum secara tegas terhadap pelaku kejahatan korupsi di masa pandemi.

Keywords: hukum Islam, hukuman, koruptor, pandemi, Covid-19 


\section{Pendahuluan}

Korupsi digolongkan sebagai tindak pidana luar biasa. Hal ini disebabkan karena keberadaannya yang sangat bertentangan dengan kemanusiaan dan berlawanan dengan semangat kesejahteraan yang terkandung dalam UUD 1945. Tujuan dan cita-cita negara untuk kesejahteraan rakyat dibangun di atas fondasi Pancasila yang telah diprakarsai oleh seluruh pendiri bangsa dan negara Indonesia. Sebagai negara hukum sudah barang tentu Indonesia memerlukan otoritas negara sebagai konsep negara hukum dalam arti formal untuk dapat mencegah tindakan korupsi sebelum ia merambah sampai ke penjuru negeri. Negara hukum dalam arti material yang sering disebut sebagai negara kesejahteraan merupakan tuntutan obyektif yang tidak dapat dikesampingkan. Selanjutnya negara-negara yang maju memandang bahwa korupsi adalah musuh negara, mengancam sendi-sendi kehidupan, dan harus diperangi secara sistematis karena menimbulkan bahaya yang besar. Negara diharuskan mengambil posisi sebagai kerangka hukum dan regulasi. ${ }^{1}$

Secara hukum, Indonesia telah memiliki suatu aturan hukum yang mengatur tentang hukuman mati. Salah satunya adalah Kitab Undang-Undang Hukum Pidana (KUHP) yang di dalamnya terdapat 9 jenis tindak pidana yang dapat diancam dengan hukuman mati, di antaranya adalah terdapat di dalam Pasal 104, Pasal 111 ayat (2), Pasal 124 ayat (1), Pasal 124, Pasal 140 ayat (3), Pasal 340, Pasal 365 ayat (4), Pasal 444 serta yang tekrahir terdapat di dalam Pasal 479 huruf k serta Pasal 479 juncto paragraf h (2) KUHP. ${ }^{2}$ Selain terdapat di dalam KUHP, hukuman mati juga terdapat di peraturan perundang-undangan di luar KUHP, di antaranya adalah terdapat di dalam UU Psikotropika, UU Pengadilan HAM, UU Tipikor, UU Tindak Terorisme, dan UU Narkotika. ${ }^{3}$

Berawal dari berlakunya undang-undang tindak pidana korupsi (UU Tipikor), hingga saat ini belum ada hakim pengadilan di Indonesia yang menjatuhkan hukuman kepada pelaku korupsi sebagai pelaku tindak pidana. Padahal undang-undang sudah menentukan siapa koruptor itu sebenarnya. Barubaru ini di tahun 2020, ada dua menteri yang ditangkap aparat penegak hukum karena tindak pidana korupsi. Salah satunya adalah korupsi dana investasi benih lobster yaitu Edhy Prabowo, dan yang lainnya adalah korupsi dana bantuan sosial (bansos) yaitu Juliari Peter Batubara. ${ }^{4}$ Dalam kasus tindak pidana korupsi bantuan sosial, perlu diperhatikan bahwa saat ini negara Indonesia, bahkan seluruh negara di dunia, sedang dilanda wabah penyakit yang sangat berbahaya yaitu Covid-19 yang membuat pemerintah memberlakukan pembatasan sosial atau karantina wilayah sehingga masyarakat membutuhkan bantuan dari pemerintah untuk memenuhi kebutuhan kehidupan sehari-hari selama masa karantina wilayah tersebut. Namun demikian, di masa kritis ini, ternyata masih ada pejabat negara yang melakukan korupsi dana bantuan yang seharusnya diberikan maksimal untuk kesejahteraan masyarakat.

Melihat fenomena tersebut, banyak pihak yang menginginkan agar tindak pidana korupsi dana bansos dijatuhi hukuman mati. Sejalan dengan penjelasan yang penulis jabarkan di atas, maka penulis mencoba mengkaji secara rinci dengan menggunakan analisis normatif apakah seorang pelaku tindak pidana korupsi dana bantuan sosial dapat dijatuhi hukuman mati atau tidak. Selanjutnya penulis juga

1 Edi Rosman, dkk, "Politik Hukum Pidana Indonesia: Analisis Korelasi SiyāSah Syar'iyyah dan Pencegahan Korupsi”, Al-Manāhij: Jurnal Kajian Hukum Islam, Vol. 13, No. 1, Juni 2019, 15-31, 20.

2 Mahrus Ali, Dasar-Dasar Hukum Pidana (Jakarta: Sinar Grafika, 2012), 196.

3 Nata Sukam Bangun, "Eksistensi Pidana Mati Dalam Sistem Hukum Indonesia”, skripsi, (Yogyakarta: Fakultas Hukum Universitas Atma Jaya, 2014), 5.

4 Tim detikcom, “Aksi KPK Tetapkan 2 Menteri Jadi tersangka Dalam Rentang 2 Pekan”, Detik.com, 6 Desember 2020, https:// news.detik.com/berita/d-5283420/aksi-kpk-tetapkan-2-menteri-jadi-tersangka-dalam-rentang-2-pekan, diakses pada 21-012021. 
akan memaparkan bagaimana pelaksanaan hukuman mati bagi pelaku tindak pidana korupsi pada saat bencana pandemi berdasarkan hukum pidana nasional Indonesia dan bagaimana ketentuan hukuman mati bagi pelaku korupsi di saat terjadi bencana pandemi menurut hukum pidana Islam.

\section{Pengaturan Hukuman Mati bagi Koruptor di Masa Bencana Pandemi di Indonesia}

Kasus korupsi sebenarnya sangat sulit dilakukan tanpa adanya bantuan dari pihak-pihak tertentu dalam suatu lembaga negara. Teknologi di bidang keuangan dan di bidang telekomunikasi telah digunakan untuk pencegahan tindak pidana korupsi. Namun demikian, ternyata yang terjadi adalah sebaliknya, yakni pelaku korupsi justru orang-orang yang seharusnya bertanggungjawab atas jalannya suatu sistem pengendalian korupsi. Hal ini terjadi karena para pelaku tindak pidana korupsi saat ini sangat pandai dan mampu memanipulasi keadaan guna mewujudkan keinginannya untuk melakukan korupsi. Tidak hanya itu, tindak pidana korupsi ini juga dilakukan oleh orangorang yang berpendidikan tinggi dengan cara yang rapi serta dilakukan dengan lebih dari satu orang atau bahkan tersistematisasi oleh sebuah kelompok jaringan. Sebab kejahatan ini merupakan suatu kejahatan yang tidak hanya dilakukan oleh perorangan saja, karena melibatkan banyak orang. ${ }^{5}$ Kasus korupsi di Indonesia dari tahun ke tahun selalu mendapatkan peringkat tertinggi dalam artian selalu meningkat mulai dari pelakunya yang semakin menyebar mulai dari pemerintah paling bawah sampai pemerintah pusat, selanjutnya dari segi kerugian negara sampai kepada trik dan kualitas tindak pidana korupsi yang semakin canggih dan menambah resah masyarakat. ${ }^{6}$ Ketua KPK mengatakan kerentanan periode 2004-2019 semakin meningkat, di mana rincian korupsi tersebar di beberapa instansi, baik di instansi Pemerintah Pusat maupun di Daerah. ${ }^{7}$ Jumlah kasus korupsi di tingkat pusat sebanyak 359 kasus, sedangkan untuk daerah yang tersebar kasus korupsi dari tahun 2004-2019 adalah Jawa Barat 101 kasus, Jawa Timur 85 kasus, Sumatera Utara 64 kasus, Jakarta 61 kasus, sedangkan di Riau dan Kepulauan Riau 51 kasus, Jawa Tengah 49 kasus, Lampung 30 kasus, Banten 24 kasus, Sumatera Selatan, Kalimantan Timur, Bengkulu, dan Papua 22 kasus. ${ }^{8}$

Dari sekian banyak kasus korupsi di Indonesia, belum ada satupun pelaku yang divonis dengan hukuman mati. Sedangkan kasus korupsi di Indonesia bukan hanya kasus korupsi biasa, namun ada kasus korupsi yang dilakukan pada saat-saat kondisi masyarakat sedang mengalami krisis. Sebagaimana dijelaskan dalam Undang-Undang Nomor 20 Tahun 2001 tentang Perubahan atas Undang-Undang Nomor 31 Tahun 1999 tentang Pemberantasan Tindak Pidana Korupsi (UU Tipikor), jika korupsi dilakukan pada saat kritis, pelakunya dapat dihukum mati. Hal itu tertuang dalam Pasal 2 ayat 2 UU Tipikor yaitu sebagai berikut:

(1) Barang siapa dengan melawan hukum melakukan perbuatan memperkaya diri sendiri atau orang lain atau korporasi yang dapat merugikan keuangan negara atau perekonomian negara, dipidana dengan pidana penjara seumur hidup atau pidana penjara paling cepat 4 tahun serta pidana penjara paling lama 20 tahun serta dikenakan pidana denda Rp.

5 Evi H, Tindak Pidana Korupsi (Tipikor) (Jakarta: Sinar Grafika, 2009), 2.

6 Evi H, Tindak Pidana Korupsi (Tipikor).

7 Iqbal M. Syahid, "Data KPK 2004-2019: Tindak Pidana Korupsi paling banyak di Pusaran pemerintah Pusat dibandingkan Kepolisian”, Seputar Tangsel, 30 Juni 2020, https://seputartangsel.pikiran-rakyat.com/nasional/pr-14581448/data-kpk-20042019-korupsi-terbanyak-di-pemerintah-pusat-polisi-paling-sedikit, diakses pada 21-01-2021.

8 Iqbal M. Syahid, "Data KPK 2004-2019". 
200.000.000,00 (dua ratus juta rupiah) paling sedikit dan Rp. 1.000.000.000,00 (satu miliar rupiah) paling banyak;

(2) Dalam hal tindak pidana korupsi sebagaimana dimaksud pada ayat (1) dilakukan dalam keadaan tertentu, pidana mati dapat dijatuhkan.

Meski sudah diatur dalam undang-undang, namun dari sisi penerapannya, hukuman mati masih menjadi perdebatan di kalangan ahli hukum pidana dan aktivis HAM di Indonesia. Adapun yang menjadi tolak ukur menentang hukuman mati adalah sebagaimana yang diamanatkan di dalam UUD 1945 bahwa setiap orang berhak atas kehidupan sendiri. Berdalil dengan alasan inilah para pendukung HAM sangat menentang adanya hukuman mati bagi koruptor di Indonesia. Tidak hanya itu, para hakim di Indonesia banyak yang berbeda pendapat terkait hukuman mati tersebut dengan dalil sebagaimana yang telah dicantumkan di dalam UUD 1945, sehingga tidak sedikit para hakim memutuskan perkara tindak pidana korupsi memberkan hukuman minimal dari yang dituntut oleh jaksa penuntut umum.

Dalam hal ini, para ahli juga memberikan tanggapan atas pasal yang menjadi tolak ukur layak tidaknya pidana mati dijatuhkan di Indonesia bagi pelaku korupsi. Menurut Marius, Pasal 2 beserta penjelasannya sangatlah sulit untuk dibuktikan secara hukum dengan sebab-sebab sebagai berikut: ${ }^{9}$

1. Untuk suatu perkara bahaya di Indonesia, pemerintah sudah secara tegas menggunakan aturan UU Nomor 6 Tahun 1946 tentang keadaan bahaya;

2. Untuk bencana alam nasional juga telah ada aturan hukum ynag mengaturnya secara tegas yaitu terdapat di dalam UU Nomor 24 Tahun 2007 tentang Penanggulangan Bencana;

3. Tidak adanya aturan yang jelas terkait dengan definisi konkrit tentang adanya keresahan sosial yang meluas;

4. Belum adanya aturan yang jelas terkait definisi konkrit tentang situasi krisis ekonomi dan moneter.

Uraian dan penjelasan di atas menggambarkan bahwa Pasal 2 UU Tipikor ternyata mengandung banyak kelemahan dalam praktiknya. Salah satu kelemahan dalam penerapan pasal tersebut adalah bahwa pasal tersebut hanya dapat diterapkan kepada pelaku sebagai upaya terakhir dalam pemberantasan korupsi serta apabila hukuman yang lain tidak dapat lagi menjangkau pelaku dengan adanya efek jera. Maka dalam hal ini perlu memperhatikan konteks hukuman mati yang sebenarnya karena beberapa hal berikut ini: ${ }^{10}$

a. Sebuah hukuman mati harus memiliki efek jera;

b. Hukuman mati harus bisa melindungi korban/ orang yang dirugikan oleh korupsinya;

c. Hukuman mati sebagai tameng pemerintah terhadap kejahatan korupsi yang merajalela;

d. Pidana mati merupakan hukuman yang sah menurut undang-undang karena telah diatur sedemikian rupa melalui aturan tertulis.

Tujuan pidana mati memang merupakan tindak pidana yang harus dijatuhkan kepada pelakunya sebagai alat terakhir dalam sistem pemidanaan baik tindak pidana khusus maupun tindak pidana

9 Mahrus Ali, Dasar-dasar Hukum Pidana (Jakarta: Sinar Grafika, 2011), 139.

10 Daniel Pascoe, dkk. Politik Hukuman Mati di Indonesia (Kota Serpong_Indonesia: MK, 2016), 121. 
umum seperti korupsi dan tindak pidana lainnya. Penerapan pidana mati juga harus memenuhi seluruh elemen-elemen yang terdapat di dalam pemidanaan seperti: pertama, ada unsur absolut, artinya pidana mati yang dijatuhkan harus bertujuan untuk menegakkan keadilan (memenuhi tuntutan keadilan), jadi pidana bukanlah alat untuk mencapai tujuan tetapi untuk mewujudkan keadilan. ${ }^{11}$ Kedua, merupakan gabungan dari keduanya, adapun unsur-unsurnya sebagai berikut: unsur gabungan lebih menitikberatkan pada balas dendam untuk melindungi ketertiban hukum, menitikberatkan pada perlindungan, dan terakhir menekankan kesamaan antara balas dendam dan melindungi kepentingan masyarakat. ${ }^{12}$

Dalam kasus ini pula, pakar hukum tata negara yang pernah menjadi Ketua Mahkamah Konstitusi, Moh. Mahfud MD mengatakan bahwa hukuman mati dapat dijatuhkan berdasarkan prinsip keberanian hakim dalam memutus perkara korupsi yang diadili. Secara sosiologis hukuman mati tidaklah begitu menakutkan ataupun sakral dalam penerapannya apalagi hukuman mati itu diberikan kepada pelaku yang telah melakukan kejahatan terhadap kemanusiaan seperti korupsi di saat bencana atau pandemi. Secara umum tujuan dan maksud diberikannya hukuman mati kepada pelaku adalah sebagaimana tujuan hukum itu sendiri yaitu memberikan rasa keadilan dan kemanfaatan serta ketertiban di dalam masyarakat. ${ }^{13}$

Sedangkan menurut salah satu mantan pimpinan KPK, Busyro Muqodas, ada kriteria yang harus dipenuhi agar pelaku korupsi dapat dijatuhi pidana mati, yaitu: ${ }^{14}$

a. Kerugian negara lebih dari 100 miliar.

b. Pelaku korupsi harus pejabat atau bekerja di instansi pemerintah.

c. Pelaku korupsi adalah residivis (korupsi berulang).

Pada kesempatan yang sama, mantan Hakim Agung, Artidjo Alkostar, mengatakan bahwa hukuman mati dapat dijatuhkan jika memenuhi unsur-unsur berikut: seperti suatu bangsa dan negara sedang dilanda suatu keadaan tertentu/ musibah ataupun marabahaya, terjadinya bencana besar yang mengakibatkan adanya kerugian secara nasional, ataupun diberikan kepada para pelaku tindak pidana korupsi secara terus menerus atau disebut dengan seorang residivis, negara berada dalam kondisi krisis, baik moneter maupun krisi bencana alam, dan hal ini merupakan elemen yang menjadi parameter yang harus dapat dibuktikan secara nasional. Penjelasan di atas secara yuridis dapat dibantah secara hukum, karena dalam UU Kekuasaan Kehakiman, hakim memiliki kuasa dalam menjatuhkan pidana kepada para pelaku yang telah disidangkan, berdasarkan ketentuan hukum material maupun hukum formal. Dalam artian hakim memiliki hak untuk menjatuhkan pidana dengan mempertimbangkan seluruh aspek yang ada baik aspek nilai-nilai yang berkembang dan rasa keadilan yang masih hidup di tengah-tengah masyarakat. ${ }^{15}$

Negara Indonesia dapat mengambil pelajaran dari negara-negara tetangga yang telah menerapkan hukuman mati bagi pelaku tindak pidana korupsi, seperti negara China, di mana negara tersebut memberikan hukuman mati kepada pelaku tindak pidana korupsi dengan tidak memandang

\footnotetext{
11 Djoko Sumaryanto, Pengembalikan Beban Pembuktian TP dalam Rangka PKN (Jakarta: Prestasi Pustaka, 2019), 110.

12 Mahrus Ali, Dasar-dasar Hukum Pidana, 191.

13 M. Sya'roni Rofii, Pidana Mati Bagi Koruptor: “Diskursus Mendesak Di Masa Kritis”. Istinbath: Jurnal Hukum, [S.L.], V. 12, 53-65

${ }^{14}$ Rosmaulina Munthe, Dkk. Kebijakan Formulasi Sanksi Pidana Mati Dalam Sistem Pemidanaan di Indonesia, DPL. V. 5, N. 4, 2016.

15 Elsa R. M. T, “Eksistensi Ancaman Pidana Mati dalam Undang-Undang Tindak Pidana Korupsi”, Jurnal Hukum Prioris, Vol. 3, No. $3,2016$.
} 
siapa yang melakukan (tanpa mempertimbangkan aspek HAM seseorang). Contoh konkritnya adalah bahwa seorang Wakil Ketua Parlemen di China yang pernah melakukan tindak pidana korupsi, hakim yang mengadili dan menjatuhkan hukuman mati kepadanya. Selanjutnya seorang Perdana Menteri di China yang belum lama ini melakukan tindak pidana korupsi, hakim yang mengadilinya juga menjatuhkan hukuman mati sebagai pidana yang harus dijalankannya.

Berlandaskan pada penjelasan di atas, sebenarnya hakim memiliki kewenangan yang sangat luas (walaupun terbatas oleh aturan hukum) untuk menjatuhkan pidana kepada pelaku tindak pidana korupsi. Sebab hukum yang diterapkan itu harus dapat memberikan rasa keadilan yang merata kepada masyarakat melalui palu sidang hakim. Selanjutnya hakim juga diberikan kewenangan untuk dapat menggali hukum dan aturan yang berkembang di dalam masyarakat, baik itu nilai-nilai moral hukum, nilai-nilai sosiologis hukum serta nilai-nilai lainnya yang dapat mendukung kinerja hukum itu sendiri. Dengan begitu ketika hakim hendak memutus suatu perkara apalagi berkaitan dengan kerugian negara pada saat pandemi saat ini, perlu adanya perluasan ataupun pemberian pidana yang setimpal dengan para pelaku tindak pidana, agar tercipta yang namanya suatu efek jera dan ketentraman di dalam masyarakat. ${ }^{16}$

Sejalan dengan itu juga, seluruh masyarakat Indonesia menaruh harapan yang tinggi kepada hakim dan penegak hukum lainnya agar para pelaku korupsi mendapat hukuman yang layak demi terciptanya keadilan dan kemakmuran masyarakat. Oleh sebab itu, perlu sebenarnya dikaji kembali aturan hukum yang mengatur tentang pidana mati bagi koruptor dilakukan pengkajian yang mendalam, apakah pasal tersebut layak atau tidak berada di dalam suatu undang-undang. Sejatinya ketika pasal tersebut sudah ada, maka harus diterapkan di dalam praktiknya, agar tidak sekedar menjadi "macan" di atas kertas. Keberlangsungan dari hukuman mati bagi koruptor juga perlu dilakukan pengkajian ulang, agar pasal tersebut tidak menjadi bomerang bagi hakim di Indonesia dalam memeriksa dan mengadili suatu perkara tindak pidana korupsi, sebab ketika hakim tidak menggunakannya maka hakim akan merasa bersalah ataupun masyarakat akan memandang hakim tersebut adalah hakim yang sudah disuap ataupun anggapan yang lainnya. ${ }^{17}$

Menurut hemat penulis, dijatuhinya pidana mati bagi pelaku tindak pidana korupsi menjadi salah satu perbaikan sistem hukum ke depannya, sebab korupsi ini sudah menjadi tradisi bagi para pejabat yang memegang kuasa. Oleh karena itu perlu adanya stimulus hukuman yang tegas dan memang benar-benar memberikan rasa keadilan bagi masyarakat agar para pelaku selanjutnya akan merasakan efek jera yang secara konkrit di dalam masyarakat. Tetapi, untuk menjalankan atau menerapkannya perlu kebijakan yang serius dari pemerintah agar hukuman mati ini benar-benar dijalankan sebagaimana mestinya. Kalau kita berkaca dari kasus-kasus yang setara dengan korupsi contohnya seperti narkoba, ${ }^{18}$ di negeri ini sudah banyak pelaku baik pengedar maupun sebagai penjual yang dihukum mati, ini menunjukkan hukuman mati sebenarnya bisa diterapkan dengan catatan diberikan ruang dan penjelasan yang tegas kepada siapa saja hukuman itu diberikan. ${ }^{19}$

16 Vivi Ariyanti, “Implementasi Asas Legalitas dan Retroaktif tentang Tindak Pidana Korupsi dalam Perspektif Hukum Islam”, Al-Manahij: Jurnal Kajian Hukum Islam, Vol. 9, No. 1, 2015.

17 Oksidelfa Yanto, "Efektifitas Putusan Pemidanaan Maksimal Bagi Pelaku Tindak Pidana Korupsi Dalam Rangka Pengentasan Kemiskinan," Syiah Kuala Law Journal 1.2 (2017): 18-36.

18 Vivi Ariyanti, "Kedudukan Korban Penyalahgunaan Narkotika dalam Hukum Pidana Indonesia dan Hukum Pidana Islam", Al-Manahij: Jurnal Kajian Hukum Islam, Vol. 11, No. 2, 2017.

19 Ady Tri Setyo Nugroho, "Pelaksanaan terhadap Penjatuhan Sanksi Pidana Mati Untuk Pelaku Tindak Pidana Korupsi”, Skripsi (Yogyakarta: Fakultas Hukum Universitas Atma Jaya, 2014). 
Namun demikian, ketika kebijakan dalam Pasal 2 UU Tipikor tersebut akan dilaksanakan, ada beberapa catatan penting yaitu sebagai berikut:

a. Hukuman mati hanya dapat diterapkan pelaku tindak pidana korupsi tertentu sehingga hanya kategori itu saja yang akan mendapatkan hukuman mati;

b. Hukuman mati hanya untuk pembobotan/pemberatan dan tidak ditujukan pada tindak pidana korupsi lainnya;

c. Pernyataan keadaan tertentu tidak dirumuskan secara eksplisit dalam rumusan pasal;

d. Undang-undang korupsi tidak memasukkan pemberatan pidana terhadap tindak pidana korupsi (residive).

\section{Pengaturan Hukuman Mati bagi Koruptor di Masa Bencana Pandemi Menurut Hukum Pidana Islam}

Dalam beberapa kajian pustaka tentang pidana Islam, istilah korupsi tidak dikenal secara eksplisit, hanya saja dikenal secara pandangan atau pendapat para ulama bidang hukum yang menterjemahkan bahwa korupsi merupakan bagian dari sebuah kejahatan. Korupsi dalam pandangan Islam dikaitkan dengan penyalahgunaan jabatan atau amanah yang diberikan oleh masyarakat kepada seorang pemimpin negara. Jika jabatan tersebut digunakan untuk melakukan perbuatan jahat dalam segala bidang yang berkaitan dengan pelanggaran atau kejahatan hukum, maka perbuatan tersebut digolongkan sebagai kejahatan, apapun jabatan yang diemban oleh para pelakunya. Jabatan yang mestinya harus dijalankan sebagaimana mestinya, namun disalahgunakan untuk kepentingan dirinya atau kelompoknya saja. Jabatan adalah amanah sehingga menyalahgunakannya adalah sebuah pengkhianatan. Hal ini sesuai dengan ketentuan sebagaimana yang Allah firmankan dalam Qur'an Surah Al-Anfal ayat 27 yang berbunyi sebagai berikut:

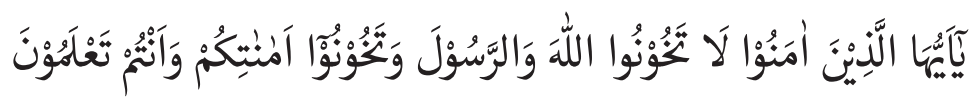

"Wahai orang yang beriman, janganlah kamu berbuat khianat kepada Allah dan Rasul (Muhammad) dan (juga) janganlah kamu mengkhianati amanat-amanat yang dipercayakan kepadamu, sedang kamu mengetahui."

Amanah yang telah diberikan kepada seseorang seharusnya dijaga dan dijalankan sesuai dengan aturan yang ada, sebagaimana perintah dari pimpinan yang memberikan amanah tersebut kepadanya. Hal ini sesuai dengan perintah Allah dalam al-Qur'an Surah al-Nisa' ayat 58 yang berbunyi:

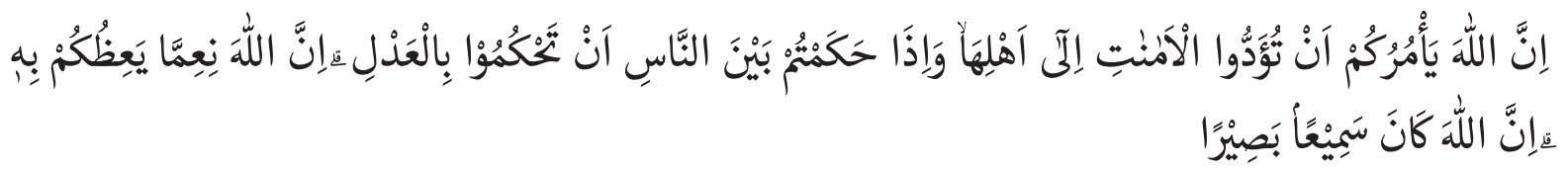

"Sesungguhnya Allah menyuruh kamu menyampaikan amanat kepada yang berhak menerimanya, dan (menyuruh kamu) apabila menetapkan hukum di antara manusia supaya kamu menetapkan dengan adil. Sesungguhnya Allah memberi pengajaran yang sebaik-baiknya kepadamu. Sesungguhnya Allah adalah Maha mendengar lagi Maha melihat."

Al-Qur'an telah menjelaskan secara bahwa suap atau korupsi adalah sebuah perbuatan yang dilarang, baik menurut ajaran agama maupun dilarang menurut hukum sebuah bangsa. Larangan ini 
terdapat di dalam Qur'an Surah al-Baqarah ayat 188 yang berbunyi sebagai berikut:

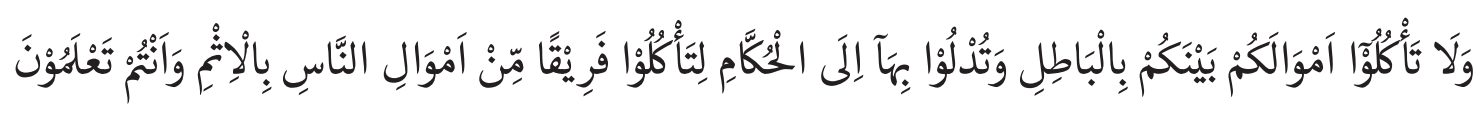

"Danjanganlah sebahagian kamu memakan harta sebahagian yang lain di antara kamu denganjalan yang bathil dan (janganlah) kamu membawa (urusan) harta itu kepada hakim, supaya kamu dapat memakan sebahagian daripada harta benda orang lain itu dengan (jalan berbuat) dosa, padahal kamu mengetahui."

Dalam ajaran Islam, korupsi lebih banyak ditampilkan sebagai tindak pidana yang sangat menyimpang dari prinsip akhlak dan etika beragama, sebab korupsi merupakan suatu perbuatan yang sangat tercela sehingga dapat merusak akhlak seseorang yang melakukannya. Tidak hanya itu, dalam agama diajarkan juga untuk tidak mengambil hak seseorang untuk kepentingan sendiri ataupun, dengan kata lain, mengambil yang sebenarnya tidak menjadi milik kita sendiri. Oleh karena itulah menurut ajaran Islam hukuman bagi mereka yang mengambil yang bukan haknya diberikan sanksi ta'zir kepadanya sebagai salah satu bentuk pidana yang diputuskan berdasarkan kebijakan lembaga yang berwenang di masyarakat. ${ }^{20}$ Lebih lanjut, korupsi sendiri dikategorikan sebagai kejahatan maliyah (keuangan) yang memiliki tiga unsur:

1. Tindakan itu harus merupakan tindakan tasarruf (mengambil tanpa hak, memanipulasi, dan lain-lain);

2. Pejabat itu melakukan tindakan khianat terhadap orang yang dipimpinnya;

3. Perbuatan itu memiliki kerugian yang nyata berdampak pada masyarakat.

Di dalam hukum Islam korupsi dapat diterjemahkan ke dalam beberapa pengertian secara etimologi. Dalam hal ini hukum Islam juga membaginya menjadi beberapa jenis dan bentuk korupsi yang sering dilakukan oleh para pelaku, yaitu di antaranya sebagai berikut: ${ }^{21}$

1. Risywah, yang menurut bahasa adalah sesuatu yang dapat menyampaikan tujuan dengan segala cara agar tujuan tersebut dapat tercapai. Pengertian tersebut diambil dari kata rasya yang artinya ember yang digunakan untuk sumur. Sedangkan al-rāsyi adalah orang yang memberikan sesuatu kepada pihak kedua untuk mendukung niat jahat dari perbuatannya. Kemudian al-rāsyi menjadi mediator atau penghubung antara pemberi suap dengan penerima suap, sedangkan penerima suap dikenal dengan al-murtasyi.

2. Al-ghulul, yaitu perbuatan menggelapkan kas negara atau baitul mal atau dalam literatur sejarah Islam menyebutnya dengan mencuri harta rampasan perang atau menyembunyikan sebagian untuk dimiliki sebelum diserahkan ke tempat pembagian. Kata "ghulul" dalam teks hadis adalah penipuan, tetapi dalam sumber lain "ghulul" berarti penggelapan yang berkaitan dengan kas negara atau baitul mal. Perbuatan yang termasuk dalam kategori alGhulul adalah:
a. Mencuri ghanimah (rampasan perang);
b. Menggelapkan kas Negara;
c. Menyembunyikan harta zakat.

$\overline{20}$ Munawar F. N, Islam dan Gerakan Moral Anti Korupsi (Jakarta: ZH, 1997), 10.

21 Abu Fida', Terapi Penyakit Korupsi dengan Takziyatun Nafs (Penyucian Jiwa), (Jakarta: P Republika, 2004), 3. 
3. Al-maksu adalah tindakan memungut cukai tanpa hak, yaitu mengambil sejumlah harta yang bukan haknya dan memberikannya kepada pihal lain yang juga tidak berhak. Tindakan ini diidentikkan dengan pungutan liar yang biasanya terjadi ketika seseorang mengurus sesuatu yang kemudian dikenakan pembayaran sejumlah tertentu oleh pemungut pajak tanpa kesediaan orang yang dipungut. Jika pungutan tidak dipenuhi oleh korban, maka urusan orang tersebut akan dipersulit oleh pemungut cukai. Inilah yang kemudian disebut al-maksu.

Hukum pidana Islam dalam kedudukannya terhadap hukum lainnya seperti hukum positif di Indonesia, hukum adat serta hukum Barat lainnya, telah banyak memberikan sumbangsih dalam pemberian norma hukuman kepada para pelaku kejahatan, tidak tertutup kepada kejahatan korupsi, di mana hukuman yang diberikan banyak yang mendasarkan kepada hukum pidana Islam. Salah satu contohnya adalah hukuman mati bagi koruptor sebagai bentuk hukuman yang maksimal dan memiliki kekuatan hukum dasar yang kuat.2 Hal ini menunjukkan bahwa hukum Islam masih mempertahankan hukuman mati untuk kejahatan tertentu, karena hukum Islam bertujuan melindungi kepentingan individu dan masyarakat. ${ }^{23}$

Di dalam literatur hukum pidana Islam ditemukan bahwa hukuman mati dapat dikategorikan menjadi tiga bagian, yaitu adanya hukuman qisas, hukuman yang berupa had (hudud), dan hukuman yang berupa ta'zir. Dalam suatu kasus yang diberikan hukuman qisas, pidana mati dapat diberikan hanya kepada para pelaku yang melakukan kejahatan yang menghilangkan nyawa orang atau pembunuhan yang direncanakan atau pembunuhan yang disengaja oleh pelaku. Ssedangkan dalam suatu perbuatan atau kasus yang diberikan hukuman hudud, pidana mati diberikan kepada para pelaku yang melakukan perbuatan yang melawan masyarakat dan negara, yang disebut dalam hukum pidana Islam sebagai tindak pidana (jarimah) zina muhsan, hiraba, bagyu, dan riddah. Terahir dalam kasus perbuatan yang dapat diberikan sanksi pidana ta'zir adalah hukuman yang diberikan kepada mereka yang melakukan perbuaatan melawan hukum atau perbuatan kejahatan yang berada di luar qisas dan hudud yang dianggap oleh negara (penguasa) sangat berbahaya bagi kelangsungan dan kemaslahatan masyarakat. ${ }^{24}$

Artinya dalam konsep hukum pidana Islam, hukuman mati hanya dapat diberikan kepada suatu perbuatan-perbuatan yang tertentu saja sehingga tidak semua perbuatan pidana dapat diberikan sanksi hukuman mati. Salah satu contohnya yaitu perbuatan melawan hukum atau kejahatan terorisme, korupsi, penyalahgunaan narkotika serta perbuatan lainnya yang dianggap sebagai kejahatan luar biasa. Perbuatan kejahatan yang disebutkan di atas, kalau kita kategorikan di dalam hukum pidana Islam dapat diberikan hukuman ta'zir kepada para pelakuknya yaitu berupa hukuman mati. Penjatuhan hukuman mati tersebut harus tetap dilaksanakan oleh penguasa atau pemimpin negara yang memiliki otoritas baik implementasi maupun prosedur pelaksanaannya. Hukuman maksimal (pidana mati) dapat dijatuhkan oleh suatu negara jika dipandang sebagai upaya efektif untuk menjaga ketertiban dan kemaslahatan rakyat. ${ }^{25}$

Pidana mati dalam hukum pidana Islam sebagaimana dijelaskan oleh para ahli hukum pidana

\footnotetext{
22 Jimly Asshiddiqie, Pembaharuan Hukum Pidana Indonesia (Bandung: Angkasa, 1996), 33.

23 Abd al-Wahab al-Khalaf, Ilmu Ushul al-Figh, (Kuwait: Dar al-Qalam, 1992), 198.

24 Abd. al-Qadir Audah, Al-Tasyri’ al-Jina’iy al-Islàmì, juz I (Beirut: Muassasah al-Risalah, 1992), 663.

25 K. Sirin, “Eksekusi Mati Trio Bom Bali”, Koran Tempo, 26 Nopember 2008.
} 
bukanlah menjadi tujuan utama dalam menghukum seseorang, tetapi suatu sarana yang harus dilaksanakan agar terciptanya keadilan dan ketentraman di dalam masyarakat. Selain itu, hukuman mati tersebut tidak menjadi hukuman final yang harus diterapkan dalam kasus-kasus yang telah disebutkan di atas. ${ }^{26}$ Oleh karena itu, penjatuhan pidana mati tersebut wajib memenuhi ketentuanketentuan yang berlandasakan kepada hukum yang berlaku, hal ini dilakukan agar mencegah terjadinya suatu penyimpangan dalam pelaksanaan atau penjatuhan hukuman mati bagi para pelaku. Kendatipun demikian, hukuman mati yang telah memenuhi syarat dan ketentuan yang berlaku, wajib dijatuhkan kepada para pelaku kejahatan tersebut, agar tercipta suatu hukum yang berkeadilan di dalam masyarakat. ${ }^{27}$

Banyaknya kasus korupsi di zaman sekarang ini lebih sering dilakukan melalui modus operandi berupa penggelapan dan penyalahgunaan kekuasaan terhadap keuangan negara yang dikelola oleh pelaku ataupun karena atas jabatan yang diemban oleh para pelaku pada saat melakukan tindak pidana korupsi. Praktik penggelapan atau korupsi di masa lalu biasanya hanya sebatas pengambilan aset kecil milik negara yang notabenanya kerugian yang diakibatkan oleh tindak pidana korupsi itu hanya bersifat nominal angka yang relatif kecil dan tidak membahayakan stabilitas perekonomian negara.

Di masa Nabi Muhammad SAW, tindak pidana korupsi juga pernah terjadi yang dilakukan oleh Sahabat Nabi dalam kapasitasnya sebagai orang kepercayaan untuk mengelola baitul mal. Namun kerugian yang diakibatkannya tidaklah sampai mengakibatkan kehancuran. Terhadap pelaku korupsi yang tersebut, Nabi Muhammad SAW memberikan sanksi berupa hukuman ta'zir. Sanksi tersebut langsung diumumkan kepada seluruh umat manusia saat itu, dengan hukuman berupa sikap tidak mau mensalati jenazahnya, serta yang paling berat hukumannya adalah Nabi mengatakan bahwa pelaku kelak akan dipermalukan di depan Allah di akhirat. ${ }^{28}$ Adapun pidana ta'zir dalam ketentuan fikih jinayah yang dapat diberlakukan kepada para pelaku tindak pidana korupsi adalah hukuman mati berupa pemenggalan kepala atau hukuman gantung, hukuman kurungan, hukuman pengasingan, dan hukuman cambuk dengan hitungan lebih kurang atau paling sedikit 40 kali. $^{29}$

Pidana ta'zir dalam kategori hukuman bagi tindak pidana korupsi merupakan suatu hukuman yang dapat dikatakan sebagai hukuman yang sangat berat, sebab dalam hukuman ta'zir tersimpan suatu tujuan hukuman yang diberikan. Pertama, ia mampu mendatangkan efek jera kepada para pelaku sehingga hukuman harus menjadi pelajaran ynag bisa mendidik para pelaku menjadi lebih baik. Tujuan lain diberikannya hukuman ta'zir ialah mengancam pelakujika mengulangi perbuatannya dengan ancaman penjara, cambuk, hingga ancaman hukuman terberat. Hukuman ini bisa diterapkan bagi pelaku kejahatan ringan. Kedua, tujuan dari pemberian hukuman ta'zir adalah bahwa pelaku akan diberikan label sebagai orang yang tercela dengan cara mengumumkan kejahatan dan dosa pelaku tindak pidana di tempat-tempat umum seperti media-media pemberitaan yang ada ataupun yang sejenisnya. Ini dilakukan agar orang lain mengetahui kejahatan yang dilakukan oleh pelaku. Ketiga, sanksi dapat diberikan kepada pelaku dengan cara dijatuhi hukuman sosial di dalam masyarakat sebagaimana yang pernah dilakukan oleh Rasul terhadap beberapa sahabatnya selama lima puluh hari dan tidak ada yang berbicara dengan mereka sampai firman Allah turun dalam Surah al-Taubah

\footnotetext{
${ }^{26}$ B. N. Arief, Bunga Rampai Kebijakan Hukum Pidana, (Bandung: Citra Aditya, 1996), 99.

27 M. Z. Khan, Islam dan HAM, (Islamabad: Islam International Publications Ltd, 1988), 74.

28 Sayyid Sabiq, Fiqh Sunnah Edisi Terbaru Jilid II, (Bandung: Beirut Publishing, 2013), 89

29 Sayyid Sabiq, Fiqh Sunnah.
} 
ayat 118. Hal ini dilakukan agar mereka dapat mengambil pelajaran dari perbuatan yang mereka lakukan. Keempat, sanksi yang diberikan kepada pelaku dapat berupa diberhentikannya pelaku dari jabatan yang diembannya, mulai dari posisi jabatan sampai kepada hal-hal yang melekat padanya karena jabatannya tersebut, seperti tunjangan gaji, tunjangan jabatan ataupun lainnya. Tujuannya agar perlaku tidak lagi merasa dirinya menjadi orang yang berkuasa atas segala sesuatu yang melekat pada dirinya, sehingga harus dilakukan pencopotan secara bersamaan agar tidak terjadi lagi kejadian yang sama terhadap pelaku maupun orang lain. ${ }^{30}$

Berdasarkan analisis terhadap bentuk-bentuk hukuman ta'zir di atas, berarti menurut hukum Islam penjatuhan sanksi pidana mati dapat diberikan kepada para pelaku yang melakukan kejahatan korupsi di masa keadaan pandemi, seperti yang terjadi pada saat ini di Indonesia. Kita semua mengetahui bahwa pandemi saat ini merupakan masa di mana semua orang merasa sangat sulit dalam menjalankan kehidupan dari segi finansial. Sebagian kehidupan masyarakat sangat bergantung pada bantuan dari pemerintah. Sehingga ketika terjadi pandemi negara sedang mengalami tatanan kehidupan yang cukup menurun dari segi sosial dan ekonomi. Artinya penulis dapat menyimpulkan bahwa jika terjadi pandemi, pidana mati dapat diterapkan kepada koruptor sesuai dengan ketentuan Pasal 2 UU Tipikor maupun ketentuan hukum pidana Islam.

Hukuman mati bagi koruptor baik secara hukum positif maupun hukum pidana Islam terdapat perbedaan yang mendasar dalam hal penerapannya serta syarat-syarat yang dibutuhkan dalam penjatuhan hukuman mati tersebut. Untuk mendukung argumen tersebut, berikut ini penulis menjabarkan dua negara yang pernah melakukan dan menerapkan hukuman mati bagi para koruptor. ${ }^{31}$

\section{Malaysia}

Negara ini memiliki cita-cita yang sangat besar dalam hal menciptakan negara yang bersih dari suatu kejahatan termasuk salah satunya adalah kejahatan korupsi. Untuk mewujudkannya negara ini membentuk sebuah aturan hukum yang dapat menjerat para pelaku tindak pidana korupsi. Adapun aturan hukum yang dibentuk dinamakan sebagai undang-undang Rasuah Prevention Act. Undangundang Malaysia ini diterbitkna pada tahun 1961 dan memberlakukannya secara nasional mulai tahun 1997. Tetapi dalam perjalanannya undang-undang ini dirasa masih memiliki kelemahan yang sangat mendasar, sehingga pada tahun 2009 dilakukan revisi terhadap undang-undang ini untuk melengkapi kekurangannya. Setelah direvisinya undang-undang tersebut, ada beberapa catatan penting dari undang-undang tersebut termasuk terkait sanksi dan pemidanaan yang diberikan kepada para pelaku korupsi di negara Malaysia. Adapun aturan yang direvisi dan ditambahkan ialah berkaitan dengan beberapa pasal yaitu di antaranya pasal 16, 17, 20, 21, 22, 23. Perubahan yang mendasar di dalam pasal tersebut ialah berkaitan dengan sanksi pidananya, yaitu sebagai berikut:32

1. Adanya batasan waktu minimal dan maksimal hukuman penjara bagi pelaku korupsi, yaitu dengan rentang waktu 14 hari minimal pidana penjara dan 20 tahun untuk maksimal hukuman penjara bagi pelaku pidana korupsi;

\footnotetext{
${ }^{30}$ NU \& Kemitraan Muhammadiyah, Koruptor itu Kafir (Bandung: Mizan, 2010), 37-38.

31 M. Wahib Aziz, "Sanksi Tindak Pidana Korupsi dalam Perspektif Fiqih Jinayat”, International Journal Ihya' Ulum al-Din, Vol. 18, No. 2, 2016.

32 Ahmad Khoirul Umam, “Islam, Korupsi dan Good Governance di Negara-Negara Islam”, Al-Ahkam, Vol. 24, No. 2, 2014.
} 
2. Adanya pembayaran uang ganti kerugian yang jumlahnya dibayarkan berlipat-lipat dari uang yang dikorupsi seperti dibayarkan menjadi dua kali lipat sampai lima kali lipat dari jumlah uang yang harus dibayarkan kepada negara sebagai ganti kerugian korupsi yang dilakukan oleh pelaku.

Tidak hanya sampai di situ, hukuman bagi korupsi tidak hanya pidana penjara tetapi ada juga hukuman mati sebagaimana terdapat di dalam pasal 16 sampai 23 dalam undang-undang tersebut. Pidana mati diberikan kepada mereka yang melakukan kejahatan korupsi sebagaimana yang telah ada di dalam Undang-Undang Tipikor Indonesia yaitu melakukan tindak pidana korupsi dalam keadaan tertentu. Hukuman mati tersebut tidak bertahan lama di dalam undang-undang itu sebab hanya berlaku pada saat tahun 1997 saja tetapi sejak direvisinya maka hukuman mati telah dihapuskan dari dalam undang-undang Malaysia tersebut. ${ }^{33}$

\section{Saudi Arabia}

Negara Saudi Arabia merupakan salah satu negara yang membangun negara dengan gerakan antikorupsi. Tetapi cita-cita ini tidak akan berjalan kalau Saudi Arabia hanya bertumpu kepada undang-undang tindak pidana korupsinya. Hal yang paling penting dalam pemberantasan korupsi di negara Saudi Arabia adalah tergantung bagaimana tujuan dari pimpinan sebuah negaranya. Apakah mereka memiliki komitment dalam pemeberantasan korupsi atau tidak. ${ }^{34}$ Di dalam undang-undang Saudi Arabia yang berkaitan dengan Tipikor hukuman bagi koruptor paling berat adalah hukuman mati, sebagaimana yang mereka nisbatkan kepada Fiqh Jinayat. Adapun hukumannya adalah hukuman ta'zir yang disesuaikan dengan putusan hakim pengadilan. ${ }^{35}$ Sampai saat ini, salah satu negara yang masih bertahan dengan hukuman mati bagi para koruptor adalah negara Saudi Arabia. Hukuman ini, mereka terapkan karena menisbatkan kepada hukuman yang berlaku sejak kepemimpinan Nabi Muhammad dan para khalifah di masa Khulafaurrasyidin, di mana hukuman ini berlaku sebagai hukum publik yang digunakan oleh pemerintah. Alasan penerapan hukuman mati adalah untuk menghormati hak asasi manusia. ${ }^{36}$

Melihat hukuman yang diberikan kepada koruptor di beberapa negara muslim, berarti ada upaya penerapan hukuman yang dapat menimbulkan efek jera bagi pelakunya maupun bagi orang lain yang berniat melakukan tindak pidana korupsi, karena hukuman yang diberikan adalah membunuh nyawa pelaku. Walaupun hal itu terlihat sangat kejam bagi penganut HAM di negara lain, namun dalam hal ini negara muslim itu sangat jelas dan sangat tegas dalam tindakan mereka terhadap pelaku kejahatan korupsi. Hukuman ini juga sejalan dengan hukum pidana yang dapat dilepaskan dalam situasi/ kondisi kritis seperti halnya hukum pidana korupsi di Indonesia yang memberlakukan hukuman mati bagi pelaku kejahatan korupsi pada masa tertentu, khususnya masa bencana alam atau masa pandemi.

\footnotetext{
33 O. Yanto, Mafia Hukum Membongkar Konspirasi dan Manipulasi Hukum di Indonesia, (Depok : Penebar Swadaya Grup, 2010), 140

${ }^{34}$ A. K. Umam, Korupsi, Islam serta Good Governance di dalam Negara-Negara Islam. Jurnal Pemikiran Hukum Islam, 24(2), 2014, 195224.

35 M. W. Aziz, Sanksi Tindak Pidana Korupsi dalam Padanagan Fiqih Jinayat. International Journal Ihya 'Ulum Al-Din, 18(2), 2016, 1

36 R. Efendi, Hukuman Mati dalam Padangan Hukum Pidana dan Hukum Pidana Islam. Jurnal Ilmiah Syari'ah, 16(1), 2017, 125-143
} 


\section{Penutup}

Kondisi pandemi penyakit Covid-19 saat ini merupakan masa di mana semua orang merasa sangat sulit dalam menjalankan kehidupan dari segi finansial. Sebagian kehidupan masyarakat sangat bergantung pada bantuan dari pemerintah. Sehingga ketika terjadi pandemi negara sedang mengalami tatanan kehidupan yang cukup menurun dari segi sosial dan ekonomi. Artinya penulis dapat menyimpulkan bahwa jika terjadi pandemi, pidana mati dapat diterapkan kepada koruptor sesuai dengan ketentuan Pasal 2 UU Tipikor maupun ketentuan hukum pidana Islam. Penjatuhan sanksi pidana mati bagi koruptor di masa keadaan pandemi menurut ketentuan hukum Islam dapat diberikan berdasarkan jenis hukuman ta'zir.

Hukuman mati bagi koruptor baik secara hukum positif maupun hukum pidana Islam terdapat perbedaan yang mendasar dalam hal penerapannya serta syarat-syarat yang dibutuhkan dalam penjatuhan hukuman mati tersebut. Melihat hukuman yang diberikan kepada koruptor di beberapa negara muslim, ada upaya penerapan hukuman yang dapat menimbulkan efek jera bagi pelakunya maupun bagi orang lain yang berniat melakukan tindak pidana tersebut, karena hukuman yang diberikan adalah mengakhiri hidup si-pelaku. Walaupun hal itu terlihat kejam bagi penganut HAM, namun dalam hal ini perlu menjadi perhatian bagi semua penegak hukum agar dapat menjalankan penerapan hukum secara tegas terhadap pelaku kejahatan korupsi terutama bagi pelaku kejahatan korupsi di masa tertentu, yaitu masa bencana alam atau masa pandemi.

\section{Daftar Pustaka}

Ali, Mahrus. Dasar-Dasar Hukum Pidana. Jakarta: Sinar Grafika, 2012.

Ali, Zainuddin. Hukum Pidana Islam, Jakarta: Sinar Grafika, 2012.

Arief, Barda Nawawi. Bunga Rampai Kebijakan Hukum Pidana. Bandung: Citra Aditya, 1996.

Ariyanti, Vivi. "Implementasi Asas Legalitas dan Retroaktif tentang Tindak Pidana Korupsi dalam Perspektif Hukum Islam”. Al-Manahij: Jurnal Kajian Hukum Islam, Vol. 9, No. 1, 2015.

Ariyanti, Vivi. "Kedudukan Korban Penyalahgunaan Narkotika dalam Hukum Pidana Indonesia dan Hukum Pidana Islam”. Al-Manahij: Jurnal Kajian Hukum Islam, Vol. 11, No. 2, 2017.

Asshiddiqie, Jimly. Pembaharuan Hukum Pidana Indonesia. Bandung: Angkasa, 1996.

Audah, Abd al-Qadir. al-Tasyri’ al-Jinaiy al-Islàmì: Muqàranah bi al-Qanûn al-Wadh'i. Beirut: Muassasah al-Risalah, 1992.

Audah, Abdul Qadir. Ensiklopedia Hukum Pidana Islam. Jakarta: Media Pratama, 2001.

Aziz, M. Wahib. "Sanksi Tindak Pidana Korupsi dalam Perspektif Fiqih Jinayat.” International Journal Ihya 'Ulum al-Din, Vol. 18, No. 2, 2016.

Bangun, Nata Sukam. "Eksistensi Pidana Mati dalam Sistem Hukum Indonesia”, Skripsi, (Yogyakarta: Fakultas Hukum Universitas Atma Jaya, 2014).

Efendi, Roni. "Pidana Mati dalam Perspektif Hukum Pidana dan Hukum Pidana Islam.” Juris: Jurnal Ilmiah Syariah, Vol. 16, No. 1, 2017.

Hartanti, Evi. Tindak Pidana Korupsi. Jakarta: Sinar Grafika, 2009.

Irfan, M. Nurul. Hukum Pidana Islam, Jakarta: Amzah, 2016.

Kartayasa, Mansur. Korupsi \& Pembuktian Terbalik: Dari Perspektif Kebijakan Legilasi dan Hak Asasi Manusia. Jakarta: Kencana, 2015. 
Khalaf, Abd al-Wahab. Ilmu Ushul al-Fiqh. Kuwait: Dar al-Qalam, 1992.

Khan, Muhammad Zafrullah. Islam and Human Rights. Islamabad: Islam International Publications Ltd, 1988.

Muhammad Abu Zahrah. Usul al-Figh. Kairo: Maktabah Muhaimar, 1957.

Munawar Fuad Noeh. Islam dan Gerakan Moral Anti Korupsi. Jakarta: Zikhru'i Hakim, 1997.

Muslich, Ahmad Wardi. Hukum Pidana Islam. Jakarta: Sinar Grafika, 2005.

Nahdatul Ulama Partnership Kemitraan Muhammadiyah. Koruptor itu Kafir. Jakarta: Mizan, 2010.

Nugroho, Ady Tri Setyo. "Pelaksanaan terhadap Penjatuhan Sanksi Pidana Mati Untuk Pelaku Tindak Pidana Korupsi”. Skripsi. Yogyakarta: Fakultas Hukum Universitas Atma Jaya, 2014.

Pascoe, Daniel dkk. Politik Hukuman Mati di Indonesia. Serpong: Marjin Kir, 2016.

Poernomo, Bambang. Hukum Pidana Kumpulan Karangan Ilmiah. Jakarta: Bina Aksara, 1982.

Prodjodikoro, Wirjono. Asas-Asas Hukum Pidana di Indonesia, Bandung: PT Refika Aditama, 2011.

Rafi, Abu Fida‘ Abdur. Terapi Penyakit Korupsi dengan Takziyatun Nafs (Penyucian Jiwa). Jakarta: Penerbit Republika, 2004.

Rofii, M.Sya'roni. "Hukuman Mati bagi Koruptor:SebuahDiskursus Mendesak di Masa Kritis." Istinbath: Jurnal Hukum, Vol. 12, No. 1, 2015.

Sabiq, Sayyid. Fiqh Sunnah Edisi Terbaru Jilid II. Bandung: Beirut Publishing, 2013.

Sirin, Khaeron. "Eksekusi Mati Trio Bom Bali”, Tempo, 26 November 2008.

Sumaryanto, Djoko. Pengembalikan Beban Pembuktian Tindak Pidana dalam Rangka Pengembalian Kerugian Negara. Jakarta: Prestasi Pustaka, 2019.

Toule, Elsa RM. "Eksistensi Ancaman Pidana Mati Dalam Undang-Undang Tindak Pidana Korupsi." Jurnal Hukum Prioris, Vol. 3, No. 3, 2016.

Umam, Ahmad Khoirul. "Islam, Korupsi dan Good Governance di Negara-Negara Islam.” Al-Ahkam, Vol. 24, No. 2, 2014.

Yanto, Oksidelfa. "Penjatuhan Pidana Mati Pelaku Tindak Pidana Korupsi Dalam Keadaan Tertentu." Jurnal Legislasi Indonesia, Vol. 14, No. 1, 2018.

Yanto, Oksidelfa. Mafia Hukum Membongkar Konspirasi dan Manipulasi Hukum di Indonesia. Depok: Penebar Swadaya Grup, 2010. 